\title{
Xenoreactive antibody response following pulmonary valve replacement using porcine bioprosthesis in the young
}

\author{
MS Kim¹* ${ }^{*}$, J Kim¹, HK Lim¹, CS Park \\ From 23rd World Congress of the World Society of Cardio-Thoracic Surgeons \\ Split, Croatia. 12-15 September 2013
}

\section{Background}

Xenoreactive antibody reaction is known to initiate the immune-mediated valve destruction. To investigate the immune effect, serum anti- $\alpha-\mathrm{Gal}$ antibody response following the pulmonary bioprosthesis implantation, including clinical factors, immunoglobulin types and patterns that might influence the anti- $\alpha-G a l$ immune response in children and young adults were studied.

\section{Methods}

Between January 2008 and February 2011, 40 patients underwent pulmonary valve replacement using a porcine bioprosthesis at an age younger than 30 years. There were 27 males $(67.5 \%)$, and the median age at operation was 14 years (1.1-27.3 years). Serum was obtained from each patient prior to the operation, 1 day after the operation, at discharge, and at the first and second outpatient clinic visits. These samples were analyzed with an enzyme-linked immunosorbent assay.

\section{Results}

Regardless of the isotype, anti- $\alpha$-Gal antibody activity was increased at discharge and at the first outpatient visit. Although anti- $\alpha-$ Gal IgG antibody activity remained increased by the second outpatient visit, anti$\alpha$-Gal IgM antibody activity did not. Anti- $\alpha-$ Gal IgG antibody activity was higher at discharge among patients younger than 15 years. Anti- $\alpha-$ Gal IgG antibody activity were more prominent at the second outpatient visit in non-blood group $\mathrm{B}$ patients $(\mathrm{A}, \mathrm{O})$.

\footnotetext{
* Correspondence: mesmerist84@gmail.com

'Department of Thoracic and Cardiovascular Surgery, Seoul National University Hospital, Seoul, Korea

Full list of author information is available at the end of the article
}

\section{Conclusions}

The implantation of a porcine bioprosthesis elicits an increased formation of anti- $\alpha-\mathrm{Gal}$ antibodies, with different patterns of IgM and IgG isotypes in children and young adults. Patient's age and ABO blood group may influence the patterns of anti- $\alpha-G a l$ immune response after pulmonary valve replacement.

The early postoperative xenoreactive immune response could be considered to influence the initial process of degenerative valve failure.

\section{Authors' details}

'Department of Thoracic and Cardiovascular Surgery, Seoul National

University Hospital, Seoul, Korea. ${ }^{2}$ Department of Thoracic and Cardiovascular Surgery, Asan Medical Center, Seoul, Korea.

Published: 11 September 2013

doi:10.1186/1749-8090-8-S1-0138

Cite this article as: Kim et al:: Xenoreactive antibody response following pulmonary valve replacement using porcine bioprosthesis in the young. Journal of Cardiothoracic Surgery 2013 8(Suppl 1):0138.

Submit your next manuscript to BioMed Central and take full advantage of:

- Convenient online submission

- Thorough peer review

- No space constraints or color figure charges

- Immediate publication on acceptance

- Inclusion in PubMed, CAS, Scopus and Google Scholar

- Research which is freely available for redistribution

\section{Biomed Central}

(c) $2013 \mathrm{Kim}$ et al; licensee BioMed Central Ltd. This is an Open Access article distributed under the terms of the Creative Commons Attribution License (http://creativecommons.org/licenses/by/2.0), which permits unrestricted use, distribution, and reproduction in any medium, provided the original work is properly cited. 